\title{
EMPLOYEES BRAND CITIZENSHIP BEHAVIOUR: FRONT-LINER VERSUS BACKSTAGE EMPLOYEES' PERSPECTIVE
}

\author{
HASNIZAM SHAARI \\ SALNIZA MD SALLEH \\ ZOLKAFLI HUSSIN \\ School of Business Management \\ Universiti Utara Malaysia
}

\begin{abstract}
Brand citizenship behaviour is a relatively new construct developed in brand literature specifically in internal branding. The main assumption is that employees' readiness and willingness to engage in brand-consistent behaviour could contribute to overall brand success. With a limited understanding of what constitutes brand-consistent behaviour, this study attempts to identify possible brand-consistent behaviour among hotel employees and compare both front-liner and backstage employees by extending the concept of organizational citizenship behaviour. Using 286 respondents from three- to five-star hotels, this study suggests a few theoretical and practical implications for the betterment of an organization's sustainable brand competitive advantage.
\end{abstract}

Keywords: Brand citizenship behaviour, brand-consistent behaviour, internal branding, brand management.

\section{Introduction}

Market evidence of dramatic changes of consumer lifestyles, unpredicted economic conditions, demanding customers, rapid changes of technology, and highly competitive market have changed the way customers and other stakeholders of the organization perceive the brand. The crux of the challenge facing marketers is to ensure their high level of brand competitiveness. In facing consumers' lack of loyalty (Donnelly \& Scaff, 2013), organizations should shift the focus from product to corporate branding which emphasizes 'organization's employees' as a means of differentiation strategies and source of sustainable competitive advantages (Kitchen \& Daly, 2002). Hence, employees who represent the brand directly are engaged in the brand 
delivery process and should be able to project favourable brand performance by displaying consistent-brand behaviour (Blumenthal, 2001). This is because an employee's attitude and behaviour is critical in a consumer's evaluation of total brand/service performance (Foster \& Cadogan, 2000; Pfeffer,1994; Parasuraman, Zeithaml \& Berry, 1985).

Liberalization of the service industry in Malaysia, which among others includes the tourism and hospitality services (New Straits Times, 2009), would create a new business landscape. Moreover, service industries forecasted to contribute $70 \%$ of the Gross Domestic Product (GDP) in 2015 (The Star, 2013). With a steadily growing number of hotels, tourists and occupancy rate yearly (Ministry of Tourism Malaysia, 2009), it is expected that the hotel industry would encounter fierce competition. Moreover, employee retention and turnover are the biggest problems facing hospitality operators over time (Mohamad, 2008). Hence, it is a challenge to both academicians and practitioners to understand to what extent employees' readiness to engage in overall brand-consistent behaviour specifically brand citizenship behaviour (BCB) is.

The study at hand attempts to identify the possible brand citizenship behaviours among hotel employees. Given the importance of employees' behaviour towards the brand in general (Burmann, Zeplin \& Riley, 2008; Shaari, Salleh \& Hussin, 2012), little is understood about how front-liners and backstage employees differ in terms of their behaviour towards the brand specifically, brand citizenship behaviour. This is because, Burmann et al. (2008) highlighted that both backstage employees and front-liners are equally crucial for holistic brand performance. Moreover, Kimpakorn and Tocquer (2009) suggested that further research should be directed to understand employees' brand commitment across departments, thus including both frontliners and backstage employees. Thus, the main objective of this study is to identify possible brand citizenship behaviour among employees and to examine whether front-liners and backstage employees differ in their brand citizenship behaviour. For the purpose of this study, front-liner employees refers to employees that have a direct contact with the customers during the service contact. According to Lovelock and Wright (2002), front-liner employees also refers to as boundary spanners that are visible to customers during service delivery such as front desk, customer service and help desk. Backstage employees refers to employees that do not have direct contact and are invisible to customers during the service contact. This includes employees in the accounts, human resource and housekeeping departments. 


\section{Literature Review}

\section{The Emergence of Brand Citizenship Behaviour Conception}

The first conceptualization of $\mathrm{BCB}$ was proposed by Burmann and Zeplin (2005) by extending the organizational citizenship behaviour (OCB) conception. The main concern of BCB is employees should voluntarily engage in brand-consistent behavior, and later contribute to overall customers' brand satisfaction.

Based on literature, brand-consistent behavior is commonly discussed based on two major streams, namely (a) in-role brand behaviour and, (b) extra-role brand behaviour. For instance, Kimpakorn and Tocquer (2009), King and Grace (2008) and Punjaisri and Wilson (2007) highlighted brand-consistent behaviour as more toward in-role brand behaviour while Morhart, Herzog and Tomczak (2009) and Burmann et al. (2008) stated that brand-consistent behaviour is best described as extra-role brand behaviour. However, there is no consistent terminology used for both concepts of brand-consistent behaviour. Another major issue is the unidimension versus the multidimension of employees' brand-consistent behaviour conception. As a brief guidance, the following Table 1 summarizes the key conception of employees' brand-consistent behaviour and its dimensions.

Table 1

Brand-Consistent Behaviour Conception

\begin{tabular}{|c|c|c|}
\hline No. Author(s)/Year & Measurement(s) & Dimension(s) \\
\hline 1. Morhart et al. (2008) & $\begin{array}{l}\text { Brand-building } \\
\text { Behaviour }\end{array}$ & $\begin{array}{ll}\text { - } & \text { retention } \\
\text { - } & \text { in-role brand behaviour } \\
\text { - } & \text { extra-role brand }\end{array}$ \\
\hline $\begin{array}{l}\text { 2. Burmann et al. } \\
(2008)\end{array}$ & $\begin{array}{l}\text { Brand } \\
\text { Citizenship } \\
\text { Behaviour }\end{array}$ & $\begin{array}{ll}\text { - } & \text { helping behaviour } \\
\text { - } & \text { brand consideration } \\
\text { - } & \text { brand enthusiasm } \\
\text { - } & \text { sportsmanship } \\
\text { - } & \text { brand endorsement } \\
\text { - } & \text { self-development } \\
\text { - } & \text { brand advancement }\end{array}$ \\
\hline
\end{tabular}

(continued) 


\begin{tabular}{llll}
\hline No. Author(s)/Year & Measurement(s) & Dimension(s) \\
\hline 3. & $\begin{array}{l}\text { Punjaisri and Wilson } \\
(2007)\end{array}$ & $\begin{array}{l}\text { Brand } \\
\text { Performance }\end{array}$ & $\bullet$ unidimension \\
\hline 4. & Henkel et al. (2007) & $\begin{array}{l}\text { Behavioural } \\
\text { Branding Quality }\end{array}$ & $\bullet$ unidimension \\
\hline
\end{tabular}

Source. Burmann et al. (2008); Henkel et al. (2007); Morhart et al. (2008) and Punjaisri and Wilson (2007)

\section{The Dimensions of Brand Citizenship Behaviour}

Brand citizenship behaviour (BCB) is a relatively new concept that explains how employees could improve their brand delivery performance by aligning their attitude and behaviour to the organization's brand. In essence, BCB refers to the employees' voluntary basis to project a number of generic employee behaviours that enhances the brand identity (Burmann \& Zeplin, 2005). BCB originated from organizational citizenship behaviour (OCB) that acknowledged the internal micro-level performance (i.e. employee's brand performance) to external target groups rather than macro-level performance (i.e. job and organizational performance) alone.

According to Burmann et al. (2008), BCB is built up by seven constructs which are believed to represent the brand-related behaviour of the employees to enhance the organization's brand success and later sustain the organization's competitive advantages. The constructs are as follows:

- Helping behaviour. Helping behavior is associated with positive attitude, friendliness, helpfulness, and empathy towards internal and external customers, taking responsibility for tasks outside of the own area if necessary such as following up on complaints. Brand consideration. Brand consideration refers to employee's adherence to brand-related behaviour guidelines and reflection of brand impact before communicating or taking action in any situation.

- Brand enthusiasm. Brand enthusiasm refers to employee's ability to show extra initiatives while engaging in brandrelated behaviour.

- Sportsmanship. Sportsmanship is associated with no complaining, even if the engagement for the brand causes inconvenience; willingness to engage for the brand even at opportunity cost. 
- $\quad$ Brand endorsement. Brand endorsement refers to employee's recommendation of the brand to others also in non-job-related situations for example, to friends, passing on the brand identity to newcomers in the organization.

- Self-development. Self-development refers to employee's willingness to continuously enhance brand-related skills.

- Brand-advancement. Brand advancement refers to employee's contribution to the adaptation of the brand-identity concept to changing market needs or new organizational competencies, such as through passing on customer feedback or generating innovative ideas.

In general, the constructs cover employees' considerations towards the brand that goes beyond their formal prescribed jobs mainly to deliver the brand promise in an appropriate manner. Thus, based on the comprehensiveness of the brand-behaviour construct proposed by Burmann and Zeplin (2005), brand citizenship behaviour will be adopted because it provides a more holistic view of brand performance in the context of employees as opposed others. However, the research findings of Burmann et al. (2008) revealed that only three out of seven constructs (namely helping behaviour, brand enthusiasm and brand development) significantly explained brand citizenship behaviour. As such, there is the need to test the construct with the new data set mainly to increase the superiority of the construct.

\section{Methodology}

A total 30 hotels (ranging from three-to five-star) in the northern region of Malaysia were approached. Unfortunately only 12 hotels agreed to participate in this study. A total of 435 sets of questionnaire were randomly distributed to the identified employees based on the hotels' name lists with the assistance of the human resource executives. However, only 314 sets of questionnaire were returned. As such, the response rate was $72.2 \%$ which is considered as high. However, only 286 were processed for further data analysis comprising 187 frontliners and 99 backstage employees.

The questionnaire asked for general information on employees brand citizenship behaviour and internal branding evidence as well as the profile of the respondents. Most of the questions used the 6-point Likert Scale, ranging from 1- strongly disagree to 6-strongly agree to avoid easy answer by simply checking 'indifferences' by the 
respondents (Garland, 1991). For the purpose of the study, the original brand citizenship behaviour measure as proposed by Burmann and Zeplin (2005) was used.

\section{Findings and Discussion}

\section{Respondents' Profile}

There is almost an even split between male and female respondents ( $46 \%$ and $54 \%$, respectively). Slightly half of the respondents were aged between 21 to 30 years old $(51.7 \%)$. In terms of ethnicity, the majority were Malays (70\%), while $12.5 \%$ were Chinese, and $11.5 \%$ were Indians. With regards to education attainment, most of the respondents had their Secondary School Certificate (61.8\%), and 34\% had attended college or university. Only 3.5\% of the respondents had primary school certificates. Almost half of the respondents were from three-star hotels (48.2\%). The rest was from four-star hotels $(23.3 \%)$, and five-star hotels (28.5\%).

The ratio of customer-contact to non-customer-contact employees is considered balanced at $65: 35$. The majority of the respondents were permanent employees $(83 \%)$, while only $17 \%$ were part-timers and contract workers. With respect to organization tenure, one third of the respondents had been working with the organization for between one and three years (32.6\%). Almost 15\% had been with the hotel for more than ten years. The majority of them had worked for one to three years. In terms of salary, almost half of the respondents were paid between RM500 to RM1000 (47.2\%). Others received higher salaries based on their experience.

\section{Dimension of BCBs}

Based on the principle component analysis with Varimax rotation, the original seven dimensions of brand citizenship behaviour were dropped into four major components which were labelled and discussed as follows:

1. Helping behaviour

Helping behaviour is conceptualized as consisting of five items. However, the principle component analysis with Varimax rotation revealed that helping behaviour is developed based on eight items ( 5 original, 2 brand consideration items, and 1 
brand enthusiasm item). As such for the study at hand, helping behaviour received three additional items.

2. Self-advancement/brand development

Self-advancement and brand development dimensions were loaded as one component. This component was labelled as selfbrand-development with five items.

3. Brand endorsement

Based on the factor analysis, brand endorsement was made up by three items with an additional item from its original conceptualization. The one item that was supposed to be loaded into sportsmanship was loaded as brand endorsement.

4. Sportsmanship

Based on the factor analysis, sportsmanship consisted of only two items as compared to three items of its original. One original item of sportsmanship were loaded as brand endorsement.

Overall, the basic requirements of the factor analysis were met where, $\mathrm{KMO}$ was above 0.50 and Barlett's test was significant. However, two items that were supposed to represent brand enthusiasm were dropped because the coefficient values were less than 0.50 . The dimensions of brand consideration and brand enthusiasm were not extracted in this factor analysis. As such, this study revealed that only four main dimensions, namely; (a) helping behaviour, (b) self-branddevelopment, (c) brand endorsement and (d) sportsmanship were identified to represent brand citizenship behaviour specifically in the Malaysian context.

\section{BCB Among Front-Liners and Backstage Employees}

The only hypothesis in this study was to examine whether front-liners and backstage employees differed in their BCB. Thus, independent $\mathrm{t}$-test was conducted. The following Table 2 summarizes the findings.

Table 2

BCB among Front-Liner Versus Backstage Employees

\begin{tabular}{llccccc}
\hline No. & Dimensions & $\begin{array}{c}\text { Frontliner } \\
\text { Mean }\end{array}$ & $\begin{array}{c}\text { Backstage } \\
\text { Mean }\end{array}$ & $\begin{array}{c}\mathrm{t} \\
\text { value }\end{array}$ & df. & Sig. \\
\hline 1. & Helping behaviour & 4.80 & 4.71 & 0.938 & 186.46 & 0.349 \\
2. & Self-brand-development & 4.59 & 4.39 & 1.665 & 170.98 & 0.098 \\
3. & Brand endorsement & 4.07 & 3.94 & 0.951 & 192.4 & 0.343 \\
4. & Sportsmanship & 3.41 & 3.07 & 2.014 & 203.65 & 0.045 \\
\hline
\end{tabular}

Source. Researcher (2015) 
Based on Table 2, the results suggested that helping behaviour, selfbrand-development and brand endorsement among employees (i.e. front-liners and backstage employees) were the same. The findings were consistent with Burmann et al. (2008) that suggested backstage employees were equally important in delivering the brand promise. Interestingly, one dimension of $\mathrm{BCB}$, namely sportsmanship was statistically significant $(p<0.045)$. It showed that there was a significant difference in sportsmanship displayed by front-liners and backstage employees in the hotel industry. In detail, front-liner employees were more favourable to engage in sportsmanship as compared to backstage employees (mean score 3.41 and 3.07 respectively). Based on literature, sportsmanship is defined as no complaining, even if the engagement for the brand causes inconvenience; willingness to engage for the brand even at opportunity cost (Burmann et al., 2008). Backstage employees do not interact directly with the customers. However, during the service delivery, backstage employees sometimes may directly deal with customers such as fulfilling guest requests. This study revealed that backstage employees were not so pleased to perform above and beyond their major roles. Backstage employees seemed unwilling to sacrifice themselves for the brand success without being rewarded properly by the management.

\section{Conclusion}

This study contributes to extend the boundary of knowledge in internal branding especially in understanding employees brand citizenship behaviour. This study contributes three major findings. Firstly, based on the studied sample, this study revealed that BCB is best explained by multidimensional conception, namely helping behaviour, sportsmanship, self-brand-development and brand endorsement. This is inconsistent with previous studies of King and Grace (2008), Morhart et al. (2009) and Punjaisri and Wilson (2007) that assume brand consistent as unidimensional construct. As far as BCB is concerned this study found support that $B C B$ is a multidimensional construct as proposed by Burmann and Zeplin (2005).

Secondly, this study extends the literature by adding one dimension of BCB as opposed to the study of Burmann et al. (2008). However, the dimension extracted from this study is relatively different from the findings of Burmann et al. (2008) except for helping behaviour and self-brand-development. Sportsmanship and brand endorsement are 
rather newly extracted to explain the brand citizenship behaviour of the Malaysian hotel employees.

Thirdly, this study concluded that both front-liners and backstage employees were willing to engage with $\mathrm{BCB}$ especially displaying helping behaviour, self-brand-development and become brand endorsers. However, only front-liner employees were found to employ sportsmanship behaviour. Due to the nature of the role of backstage employees, they seem to be unfavourable toward sportsmanship.

This study also helps the hotel management to understand their employees' willingness to support the organization's brand image through their positive and consistent-brand behaviour. Given that both front-liners and backstage employees are crucial in building sustainable brand advantage such as BCB, the management should seek a formula to stimulate such behaviour among their employees. Internal branding practices such as internal brand communication, brand training, brand leadership, brand rewards, brand culture and structure are identified as key enablers for employees' brand performance. Thus, future studies should attempt to link these enablers to BCB.

\section{References}

Blumenthal,D.(2001). Internalbranding:Doesitimproveemployees' quality of life? Retrieved from http://www.instituteforbrandleadership.org

Burmann, C., \& Zeplin, S. (2005). Building brand commitment: A behavioral approach to internal brand management. Brand Management, 12(4), 279-300.

Burmann, C., Zeplin, S., \& Riley, N. (2008). Key determinants of internal brand management success: An exploratory empirical analysis. Brand Management, 21(1), 1-19.

Donnelly, C., \& Scaff, R. (2013). Who are the millennial shoppers? And what do they really want? Retrieved from http://www. accenture.com/us-en/outlook/Pages/outlook-journal-2013who-are-millennial-shoppers-what-do-they-really-want-retail. aspx

Foster, B. D., \& Cadogan, J. W. (2000). Relationship selling and customer loyalty: An empirical investigation. Marketing Intelligence and Planning, 18(4), 185-199.

Garland, R. (1991). The mid-point on a rating scale: Is it desirable? Marketing Bulletin, 2, 66-70. 
Kimpakorn, N., \& Tocquer, G. (2009). Employees' commitment to brands in the service sector: Luxury hotel chains in Thailand. Journal of Brand Management, 16, 532-544.

King, C., \& Grace, D. (2008). Internal branding: Exploring the employee's perspective. Journal of Brand Management, 15, 358372.

Kitchen, P. J., \& Daly, F. (2002). Internal communication during change management. Corporate Communication: An International Journal, 7(1), 46-53.

Lovelock, C. H., \& Wright, L. K. (2002). Principles of service marketing and management. USA: Prentice-Hall.

Ministry of Tourism Malaysia. (2009). Malaysia hotel and rooms supply. Retrieved from http//:www.tourism.gov.my/tourismmalaysia_ corpx/rpt5_roomsupply. cfm?rpt=5

Mohamad, S. F. (2008). Effects of communication on turnover intention: A case of hotel employees in Malaysia. Retrieved from http://lib. dr.iastate.edu/cgi/viewcontent.cgi?article $=2193 \&$ context=etd

Morhart, F. M., Herzog, W., \& Tomczak, T. (2009). Brand-specific leadership: Turning employees into brand champions. Journal of Marketing, 73, 122-142.

Move to liberalise economy. (2009, April 23). New Straits Times, p.1.

Parasuraman, A., Zeithaml, V. A., \& Berry, L. L. (1985). A conceptual model of service quality and its implications for future research. Journal of Marketing, 49, 41-50.

Pfeffer, J. (1994). Competitive advantage through people: Unleashing the power of the workforce. Boston: Harvard Business School Press.

Punjaisri, K., \& Wilson, A. (2007). The role of internal branding in delivery of employee brand promise. Brand Management, 15(1), 57-70.

Shaari, H., Salleh, S. M., \& Hussin, Z. (2012). Relationship between brand knowledge and brand rewards and employees' brand citizenship behavior: The mediating role of brand commitment. International Journal of Business \& Society, 13(3), 335-354.

The Star (2013). MITI confident services sector to contribute $70 \%$ of GDP by 2015. Retrieved from http://www.thestar.com.my 